\title{
The Role of International Organisations in the Development of Public Health Nursing, 1933-1974
}

María Eugenia Galiana-Sánchez

\section{Summary}

This paper analyses the contribution made by the League of Nations (LoN) and the World Health Organisation (WHO) to the development of public health nursing, and the role of nursing experts working in these and other organisations.

The sources consulted included documentation on public health nursing held in the LoN archives and technical reports drawn up by expert committees on nursing and related fields held in the WHO database.

In the 1920s, international organisations began seeking to meet the need for public health nurses who could implement community-based interventions, deploying various strategies to achieve this goal over the course of the $20^{\text {th }}$ century.

The work of nursing experts on the LoN Hygiene Committee and WHO Advisory Committees underpinned systematic efforts to establish appropriate training in public health nursing and to organise effective nursing services in Europe. The role they played reveals changing attitudes towards the contribution of public health nursing.

Keywords: public health nursing, international organisations, WHO, League of Nations, Europe

María Eugenia Galiana-Sánchez, Campus de San Vicente del Raspeig, P.O. Box 99, E-03080 Alicante (galiana@ua.es) 


\section{Introduction*}

Throughout the $20^{\text {th }}$ century but especially in the inter-war period, Europe witnessed the formation of what has been called "the international health movement", which helped establish a social and political context conducive to attaining higher levels of health and well-being. This was promoted by achievements such as the creation of public health authorities in Europe, ${ }^{1}$ the development of public health promoted by the Rockefeller Foundation ${ }^{2}$ and the League of Nations ${ }^{3}$ and structured collective efforts based on the work of experts: committees were created, international conferences held and technical reports drawn up by international health organisations. Ultimately, the aim was to promote the establishment of a central framework of reference for the exchange of health care knowledge and practices. ${ }^{4}$

In this context, international organisations and agencies promoted a health care model during the inter-war period that focused on improving public health, and implemented models of care that in the first instance would meet the immediate needs of refugees and tackle the problem of disease transmission, and would subsequently consolidate national and international public health services. ${ }^{5}$ Consequently, it was necessary to train health professionals and provide appropriate training and working conditions. ${ }^{6}$ Public health nurses, so necessary in the post-war period to carry out the humanitarian work of organisations such as the International Red Cross, were among the professional groups in which these organisations were most interested. ${ }^{7}$ Nurses slotted perfectly into the new health care model developed in the fields of social medicine and public health. ${ }^{8}$

The few studies in the literature that have examined the international history of public health nursing have primarily focused on the training provided by international organisations during the inter-war period. ${ }^{9}$ In previous

\footnotetext{
* I would like to thank Josep Bernabeu-Mestre for providing insightful comments on an earlier version of this paper.

1 Barona/Bernabeu 2008.

2 Weindling 1997, 269-281; Farley 2004; Barona 2015.

3 Borowy 2009; Weindling 1995, 134-153; Dubin 1995, 56-62.

4 Andresen/Groenlie 2007; Barona 2012.

5 Weindling 1995; Andresen/Groenlie 2007.

6 McGann 2008, 29.

$7 \mathrm{XV}^{\text {th }}$ International Red Cross Conference, Tokyo 1934.

8 Dingwall/Rafferty/Webster 1988.

9 Rafferty 1995, 266-282; Lapeyre/Nelson 2010, 33-44; Brooks/Rafferty 2010, 142-250; Irwin 2011, 78-102; McGann 2008.
} 
studies, our own research group also adopted an international perspective, conducting comparisons with the situation in Spain. ${ }^{10}$

The aim of the present study was to analyse the contribution made by international organisations (basically the League of Nations and the World Health Organisation) to the development of public health nursing services, as well as the role of nursing experts working within the framework of these and other organisations such as professional associations and societies. The sources consulted included documentation on the development of public health nursing held in the LoN archives in Geneva (correspondence, conference proceedings and monographs) and technical reports drawn up by expert committees on nursing and related fields held in the WHO database.

\section{Background: International Collaboration in the Formation of Public Health Nursing - "The Old Internationals"}

After the First World War, the need for nurses in countries devastated by the war generated a climate of international cooperation promoted by the League of Red Cross Societies. ${ }^{11}$ The first international conference of the newly established organisation, held in Cannes in 1919, presented a prime opportunity for the nursing delegation in attendance to attempt to redress the widespread ignorance in most European countries of what an effective nursing service should be. However, the infrastructures required to provide the necessary training were non-existent in the majority of countries. Given this situation, the delegation advised the League to organise an international public health course to deliver public health training to groups of selected nurses from various European countries. These students would subsequently be responsible for directing public health nursing programmes in their respective countries. ${ }^{12}$ The course was conceived as specialist training in pub-

10 Bernabeu-Mestre / Galiana-Sánchez 2011, 363-366; Galiana-Sánchez / Bernabeu-Mestre / García-Paramio 2011, 385-389.

11 The League of Red Cross Societies was founded in Cannes in 1919. The experience of the war showed that the National Red Cross Societies also needed to cooperate closely in times of peace. The Red Cross Societies of the USA, Great Britain, France, Italy and Japan were the first members of the League. http: //www.nobelprize.org/nobel_prizes/peace/ laureates/1963/red-cross-league-facts.html 2015.

12 A distinction should be made between the League of Red Cross Societies and the International Committee of the Red Cross in Geneva, which wielded greater autonomy and had different goals and strategies. When the League of Red Cross Societies was founded, it incorporated a large delegation of nurses, who played an important role in establishing the public health agenda (McGann 2008, 29-31). For its part, the International Committee of the Red Cross focused on alleviating the effects of the war, and was more closely linked to the military. See: Palmieri 2012. 
lic health, and was therefore strictly limited to qualified nurses. This entailed certain difficulties due to wide variations in training in the students' places of origin. The courses were delivered over eighteen years, training a total of 350 nurses from 47 countries. One of the results of this training initiative was the creation in 1925 of "The Old Internationals" students' association, whose members were spread throughout Europe and held positions of responsibility in their different countries of origin. ${ }^{13}$ The course programmes were inspired by the American vision of public health, influenced by the principles promoted by the Rockefeller Foundation. Spain is one example of the influence of the Rockefeller Foundation in structuring public health nursing services. The profession of public health nursing was novel in Spain in the 1920s and 1930s, but would play a key role in implementing the health policy reform which had been designed throughout the first three decades of the 20th century. ${ }^{14}$ With the advent of the Second Republic in the 1930s, health policies made it possible to intensify State participation in health campaigns and move towards a health care model in which disease prevention and health promotion were fundamental for modernisation..$^{15}$ This process reached its culmination with the scientific and health collaboration agreements signed with the Rockefeller Foundation in 1922, in which the Foundation undertook to cover the costs of a future school for visiting nurses and to finance appropriate public health training for those who were to teach in this institution. Between 1931 and 1934, the programme benefited fourteen nurses, who studied in the United States for an average of two years. ${ }^{16}$

As the example of Spain shows, these international training initiatives prompted an intense debate concerning new approaches to public health training for nurses. They also highlighted the benefits of transnational collaboration and the exchange of scientific knowledge in the field of nursing, and provided a considerable number of professionals who, as we shall see, transmitted the knowledge and experience obtained in training to their countries of origin and to international organisations such as the WHO.

13 Lapeyre/Nelson 2010.

14 Bernabeu-Mestre / Gascón-Pérez 1999.

15 Huertas 1995; Barona/Bernabeu 2008; Rodríguez Ocaña / Martínez-Navarro 2008.

16 Gascón-Pérez / Galiana-Sánchez / Bernabeu-Mestre 2002, 149-174; Bernabeu-Mestre et al. 2013, 284-289. 


\section{The League of Nations: Advising on Nurse Training and Drawing up Reports on the Situation in Europe}

After the launch of the League of Nations in 1919, the need to fight and prevent disease and carry out urgent health interventions prompted the creation of the League of Nations Hygiene Committee in 1923, which was responsible for establishing the League's health policy guidelines. ${ }^{17}$ Its director, Dr. Hazeman, and the technical adviser and nursing expert for the Hygiene Section, the nurse Hazel Avis Goff, ${ }^{18}$ together coordinated the debate on the situation and prospects of public health nursing in Europe. Goff, a regular participant on the Rockefeller Foundation International Health Board, had graduated from the Massachusetts General Hospital School and held a Bachelor of Science from Columbia University. In the United States, she directed the nursing service at the James Walker Memorial Hospital. In Europe, she was appointed in 1922 to reorganise a Bulgarian school of nursing in accordance with the Anglo-American model, and was the director of the University School of Public Health and Bedside Nursing in Poland, as well as another school of nursing in Istanbul. ${ }^{19} \mathrm{Goff}$ also advised national health organisations and the Hygiene Committee itself. She sometimes acted as spokesperson for the League of Nations, in communication with agencies and organisations such as the International Red Cross, ${ }^{20}$ various national ministries of health and institutions responsible for nurse training. ${ }^{21}$ Goff is an example of the Rockefeller Foundation's participation in the League of Nations Hygiene Committee. Through the incorporation of health experts, in this case an expert in public health nursing, the Foundation's principles and guidelines were disseminated among international organisations such as the League of Nations. ${ }^{22}$ Goff's contribution essentially encompassed two aspects: analysis and discussion of nurse training, and assessment, analysis and preparation of reports on public health nursing in ten European countries, questions that will be discussed below.

17 Barona/Bernabeu 2008, 149-150.

18 Commission Consultative des Questions Sociales, Sous-Comité pour l'etude de la formation des personnes employées dans la Service Social, (Health Section. 8A dossier 7283), (LNA, 15 February 1939).

19 Ramos Ferreira 2012, 246-247.

20 Correspondence of J. Molnárova (Nursing Section of Czechoslovak Red Cross) to Hazel Avis Goff (Health Section. 8A dossier 7283) (LNA 1934).

21 Correspondence of Hazel Avis Goff to Miss A. Sayle, Honorary Secretary of Joint Consultative Committee of Institutions recognised by the Minister of Health for the training of Health Visitors and of Organisations of Health Visitors (Health Section. 8A dossier 7283) (LNA 6 October 1933).

22 Barona 2015. 
Training in public health nursing in Europe was one of the subjects that provoked greatest contention between the League of Nations and the nursing authorities of the time. Courses differed widely between one country and another and there was no consensus on what type of training was most in keeping with the functions of a nurse..$^{23}$ Within the League of Nations, debate took place to define the educational standards that would produce competent public health professionals. ${ }^{24}$ As mentioned earlier, this debate included the proposals of the Rockefeller Foundation, which for decades had played a key role in nurse training. Developing public health nursing was crucial for the success of the health campaigns and local health departments that the Rockefeller Foundation had been helping to establish internationally. Based on these approaches, public health training enabled nurses to participate actively through specific and coordinated actions in health campaigns to fight infectious diseases such as tuberculosis or trachoma, as well as in the field of maternal and child health care. ${ }^{25}$ In the case of Spain, their participation in the tuberculosis campaign featured initiatives of great interest. At tuberculosis clinics and on home visits, they conducted home inspections, drew up house plans distributing the families to reduce the chances of infection and provided education on hygiene practices. ${ }^{26}$ They also played a major role in the health campaign against trachoma, an eye disease that frequently caused blindness. In this case, they participated in school inspections ${ }^{27}$ conducted family and community assessments ${ }^{28}$ and delivered hygiene and health education. They also played a central role in what was known as the "child care movement" and in mother and child hygiene campaigns. The work carried out with mothers through home visits is a prime example of the outreach activities nurses engaged in. Interventions were carried out in the family home, where the child lived and the conditions of hygiene could be observed. During their visits, nurses would scrutinise the home, inspecting patios, ventilation, lighting and sanitation, and offered solutions for the hygiene problems affecting the family. They instructed mothers on aspects such as breastfeeding, bathing, washing clothes, sleep,

23 Correspondence of H. A. Goff to Miss A. Sayle (LNA 1933).

24 Correspondence of Hazel Avis Goff to Dr.Hazeman, (Health Section. 8A dossier 7283) (LNA, 27 February 1939).

25 Pozzi, Bernabeu-Mestre / Galiana-Sanchez 2017, 39-56; Galiana-Sánchez / BernabeuMestre 2011, 225-248.

26 Verdes Montenegro 1934, 11-12.

27 In the campaign against trachoma, the disease was considered the result of poverty, and therefore with multiple aetiologies and approaches; see Bernabeu-Mestre, GalianaSánchez / Cremades / Monerris 2013, 1605-1619. On nursing interventions in schools, see Bernabeu-Mestre/Galiana-Sánchez 2011, 507-520.

28 Socias, Delgado 1939, 4; Selfa 1940, 163-77; Mezquita 1955, 481. 
cots and walks, and took any necessary prevention measures such as isolation of the sick, case control and disinfection. ${ }^{29}$

However, as other authors have indicated ${ }^{30}$ it would appear that the interest in nursing displayed by organisations such as the Rockefeller Foundation was not motivated by a desire to promote the autonomous development of nurses, but by the demands of health education and public health programmes. Public health nurses were good grass-roots workers, primarily focusing on practical activities and functions in direct contact with the population. ${ }^{31}$

However, the influence of the US approach to nurse training prompted a more innovative and practical vision of nursing that contrasted with the conservative, traditional view of nursing in Europe and within the International Nursing Council itself. Improving the educational and professional standards of nursing in line with the vision advanced by the Rockefeller Foundation entailed providing a university education in nursing, as had already happened in the US in 1923, when Yale University opened its school of nursing. ${ }^{32}$ However, in the debate in Europe, coordinated by the League of Nations, ${ }^{33}$ diverse opinions existed as to what a public health nursing curriculum should contain. ${ }^{34}$ There were essentially three positions. The first made a distinction between general nurse training and public health nurse training (in this case, the latter was understood in the sense of a social worker). ${ }^{35}$ The second considered that general nurses were already equipped by their training to work as public health nurses without the need for additional training, ${ }^{36}$ while the third stance, proposed by Hazeman and Goff, advocated a core training course which would split into two branches in the second year so that students

29 Bernabeu-Mestre / Perdiguero / Barona 2007, 175-193.

30 Rafferty 1995, 268.

31 As Rafferty has indicated $(1995,267)$, there were three levels of public health workers: the heads, responsible for planning, organisation and administration; the specialists, who were experts in specific public health disciplines, and those whom she has termed "the foot soldiers", who carried out the majority of practical tasks. Nurses were mainly considered to fall within the latter category.

32 This had already happened in the United States (Rafferty 1995, 269), but the abundant documentation up to 1940 concerning nurse training in Europe does not contain any reference in this regard.

33 Correspondence of H. A. Goff to Miss A. Sayle (LNA 1933).

34 It is important to note that with the exception of Goff's contributions, the documents consulted in the League of Nations archives came from heads of medical and public health training institutions rather than from nursing leaders.

35 Correspondence of J. Greenwood Wilson, Medical Officer of Health and School Medical Officer to Dr. R.H.Hazeman, (Health Section. 8A dossier 7283) (LNA, 20 May 1939).

36 Correspondence of Ralph M.F.Picken (predecessor of J. Greenwood Wilson) to J. Greenwood Wilson, Medical Officer of Health and School Medical Officer, (Health Section. 8A dossier 7283) (LNA 20 May 1939). 
could receive specific material depending on whether they wished to become public health or hospital nurses. In the opinion of the leaders of the League of Nations, training had focused strongly on hospital settings and it was necessary to include more on public health nursing. ${ }^{37}$

Goff also indicated her concern about the overlap of responsibilities between public health nurses and other community professionals, of which there was a wide variety; their functions were not always clearly demarcated, creating conflicts of responsibility. It was necessary to more clearly define the curricula for health visitors, public health nurses, district nurses and social workers in order to establish complementary functions. ${ }^{38}$

As noted above, another fundamental contribution of the League of Nations Hygiene Committee was to conduct national surveys in order to analyse the situation of public health nursing services. The results were published in a series of reports on 10 countries, which were planned and written by H. A. Goff. ${ }^{39}$ Besides the reports, she also wrote the scientific publications and communications at conferences that derived from this work. ${ }^{40}$

The countries analysed were Austria, ${ }^{41}$ Bulgaria, ${ }^{42}$ Greece ${ }^{43}$ Finland ${ }^{44}$ Hungary, ${ }^{45}$ Yugoslavia, ${ }^{46}$ Norway, ${ }^{47}$ Poland ${ }^{48}$ Czechoslovakia ${ }^{49}$ and Rumania. ${ }^{50}$ These were selected and the reports written in line with the recommendations of the European Commission on Rural Hygiene issued in 1931. ${ }^{51}$ These recommendations were to implement initiatives based on the principles of social medicine that would meet the main health and hygiene needs

37 Correspondence of H. A. Goff to Dr. Hazeman (LNA 1939).

38 Known as Fürsorgerin in Austria and Germany, correspondence of H. A. Goff to Miss A. Sayle (LNA 1933).

39 Commission Consultative des Questions Sociales (LNA 1939).

40 Her published works included "Trends in the Development of Public Health Nursing in Europe" in the International Nursing Review in 1931, and "Report of a Study of Public Health Nursing in Europe", in the International Nursing Review in 1932. She also presented the paper "Report of the Standing Committee on Public Health Nursing", subsequently published in the Proceedings of the International Congress held in Paris and Brussels in 1933.

41 Hazel Avis Goff, Nursing in Austria (Health Section. 8A dossier 7283, doc. 37294) (LNA 1933-34).

42 Hazel Avis Goff, Nursing in Bulgaria (Health Section. 8A dossier 7283) (LNA 1933-34).

43 Hazel Avis Goff, Nursing in Greece (Health Section. 8A dossier 7283) (LNA, 1933-34).

44 Hazel Avis Goff, Nursing in Finland (Health Section. 8A dossier 7283) (LNA 1933-34).

45 Hazel Avis Goff, Nursing in Hungary (Health Section. 8A dossier 7283) (LNA 1933-34).

46 Hazel Avis Goff, Nursing in Yugoslavia (Health Section. 8A dossier 7283) (LNA 1933-34).

47 Hazel Avis Goff, Nursing in Norway (Health Section. 8A dossier 7283) (LNA 1933-34).

48 Hazel Avis Goff, Nursing in Poland (Health Section. 8A dossier 7283) (LNA 1933-34).

49 Hazel Avis Goff, Nursing in Czechoslovakia (Health Section. 8A dossier 7283) (LNA 193334).

50 Hazel Avis Goff, Nursing in Rumania (Health Section. 8A dossier 7283) (LNA 1933-34).

51 Commission Consultative des Questions Sociales (LNA 1939). 
of the rural world: maternal and child health, control of preventable diseases and improved hygiene practices. ${ }^{52}$ The fact that the Commission's recommendations included determining the present situation of public health nursing in the abovementioned countries indicates the importance attributed in the field of hygiene and social medicine to the work of nurses in the community.

Each survey consisted of planning and implementing an exhaustive process of data collection, analysis and diagnosis to identify needs and propose improvements for the future. The methodology employed was based on one or more approximately month-long visits to the country in question, although in some cases, as in the study of Austria, the visit could last for two months. During this time, Goff visited the most important cities in the country, which were selected according to the nursing services or training facilities located there. Information was collected from three sources: interviews with relevant people (officials, nurses, school directors, social workers, etc.), ${ }^{53}$ observation and collection of documents of interest in health institutions, ${ }^{54}$ and lastly, scientific information from publications in the country. ${ }^{55}$

This information was used to obtain a detailed description of the situation of nursing in each of the countries and conduct an assessment based on the following aspects: the general concept of nursing in the country, which yielded information on attitudes towards the discipline, the regard in which it was held in society and possibilities for future improvements. The reports gave as accurate and precise a definition as possible of "public health nursing" in each of the countries, describing its function and professional opportunities. They also detailed the different types of workers engaged in nursing, of which there was a wide variety, ${ }^{56}$ described the training characteristics of institutions and analysed the training programmes. All this was used to diagnose the situation of nursing in each of the countries, focusing on specific problems related to public health. Some reports also discussed legislation

52 Ruesta et al. 1934, 235-279.

53 Numerous interviews were held: for example, twenty-nine interviews were conducted in Czechoslovakia (H.A.Goff, Nursing in Czechoslovakia (LNA 1933-34)), seventeen in Austria (H.A.Goff, Nursing in Austria (LNA 1933-34)) and eighteen in Bulgaria (H. A. Goff, Nursing in Bulgaria, (LNA 1933-34)).

54 Taking Finland as an example, the following institutions were visited, among others: the State Department of Health, the Anti-tuberculosis Association of Finland, General Mannerheim's Child Welfare League, the Nurses' Association of Finland, the National League for Trained Nurses of Finland, the Deaconess Hospital, the Helsinki State School for Nurses, the Surgical Hospital of Helsinki, the Society for Improving Public Health in Swedish Finland, the Helsinki Preliminary School for Nurses and the Social Welfare Museum (H. A. Goff, Nursing in Finland (LNA 1933-34)).

55 The publications consulted on Hungary included Steller 1932 and Roberts 1931.

56 For example, the report on Austria identified the following categories: "practical nurses", "partially trained nurses", "religious sisters and brothers", "male nurses", "qualified nurses" and "fürsorgerin", (H. A. Goff, Nursing in Austria, (LNA 1933-34)). 
related to nursing. ${ }^{57}$ To conclude, Goff identified the specific needs of each country and its future possibilities and prospects, always highlighting the positive aspects and encouraging institutions to enhance these and work to overcome the difficulties.

The reports, which were subsequently submitted for consideration to the League of Nations Advisory Committee on Social Questions, ${ }^{58}$ were extremely useful, as acknowledged by the above committee and indicated by the abundant correspondence from various institutions requesting them as guidelines for their own countries. ${ }^{59}$ They were also submitted to the International Nursing Council, whose Executive Secretary, Anna Schwarzenberg, regarded them very highly. ${ }^{60}$ As noted earlier, the reports served as the basis for subsequent scientific publications and were also used as supporting documentation by Hazeman in his role as a member of League of Nations commissions and committees. ${ }^{61}$

The work carried out by the League of Nations through its Hygiene Committee, together with Goff's contribution as expert advisor in the field of public health nursing, underpinned systematic efforts to establish appropriate training in public health nursing and organised, effective nursing services in Europe. The launch of the World Health Organisation in 1948 was accompanied by the creation for the first time in nursing of expert committees which established new approaches and strategies to improve hygiene and nursing, as will be discussed below. This new vision demanded improvements in training and professional conditions, but above all emphasised the contribution of these to progress in public health and social medicine.

\section{The New Considerations of the WHO: Technical Reports of the Expert Committee on Nursing}

Delegates to the first World Health Assembly, convened by the newly created WHO and held in Geneva in 1948, considered that "a larger, more competent

57 Only some of them considered this aspect, for example the report on Finland (H. A. Goff, Nursing in Finland, LNA (1933-34)).

58 Commission Consultative des Questions Sociales (LNA 1939).

59 Correspondence of Dr. R.H.Hazeman to Miss Venny Snellman, State Department of Health, Helsingfors, Finland (Health Section. 8A dossier 7283) (LNA, 16 April 1934), Correspondence of Dr. R.H.Hazeman to Dr. M.Sulc, Director Social Health Department Czechoslovak Red Cross in Prague (Health Section. 8A dossier 7283) (LNA 16 April 1934), correspondence of J. Molnárova to Miss H. A. Goff (LNA 1934).

60 Correspondence of Anne Schwarzenberg, Executive Secretary, International Council of Nurses to Dr. Hazeman (Health Section. 8A dossier 7283) (LNA 16 May 1939).

61 Commission Consultative des Questions Sociales (LNA 1939). 
nursing staff was essential in order to expand and improve health services in a country". ${ }^{62}$ One of the first measures taken to achieve this was the creation of an Expert Committee on Nursing composed of the principal authorities in the international arena. Members of this first committee included Olive Baggallay, head of the WHO Nursing Section and one of the first tutors on the course organised in the 1920s by the International Red Cross, which gave rise to the "Old International" association, and Daisy Bridges. Like Baggallay, she was also a member of the "Old International", and had replaced Anna Schwarzenberg as Executive Secretary of the International Nursing Council. ${ }^{33}$ The committee also included nurses who had been appointed to positions of responsibility in countries such as France, India, New Zealand, Chile, the USA, Finland, the United Kingdom and Switzerland, and represented institutions and organisations such as the Red Cross, the Rockefeller Foundation, national ministry departments of health and schools of nursing. The committee's first report was published in November 1950 and reflected the conclusions of the first session held in February of the same year. ${ }^{64}$ This was followed by other reports addressing different areas of nursing, including the field of public health. ${ }^{65}$

By the end of the 1940s, nurses remained in short supply due to economic and social development factors, the view of nursing as an essentially female task and poor public regard. ${ }^{66}$ Sex began to be considered a particularly important factor: "The social status of women and nurses may be the deciding factor when electing to undertake certain activities or not." ${ }^{67}$

Besides creating a group of nursing experts to mitigate these shortcomings, the WHO also established a strategy of international alliances with partners such as the International Nursing Council, the International Catholic Committee of Nurses and Medico-Social Assistants, the Nursing Bureau of the League of Red Cross Societies and the International Confederation of Midwives. ${ }^{68}$ It also created international nursing teams composed of a principal nurse instructor, a midwife instructor and a public health nurse, in order to meet the demands received from various countries to organise their nursing services. ${ }^{69}$ In 1948, these teams consisted of seven nurses, but by 1957 this figure had grown to 155 and work had been carried out in 44 countries. ${ }^{70}$

62 WHO 1958, 391-402.

63 McGann 2008, 57.

64 WHO 1950.

65 WHO 1959, 1966, 1974.

66 WHO 1958, 392.

67 WHO 1959, 12.

68 WHO 1958, 401.

69 WHO 1958, 392.

70 WHO 1958, 400-2. 
The proposed school of nursing curriculum reform spearheaded by the $\mathrm{WHO}^{71}$ was based on three elements: the inclusion of public health in basic training, the incorporation of training in maternal and child care and nurse training for teaching and administration. Nurses were thus incorporated into "a comprehensive programme to promote health, improve social and material conditions, prevent illnesses and physical disabilities and provide the corresponding rehabilitation". ${ }^{72}$

The WHO proposed nurse participation in health check-ups and examinations, paediatric clinics, vaccinations and other health protection activities. ${ }^{73}$ In fact, all these activities can be summarised under two broad headings: health education and community mediation. ${ }^{74}$ The value the WHO placed on these two roles improved public regard for public health nursing professionals. In addition, these roles were expanded to include functions such as curriculum planning ${ }^{75}$ teaching, ${ }^{76}$ the management and direction of nursing services ${ }^{77}$ and research..$^{78}$

In order to put these proposals into practice, the WHO established a series of guidelines that involved major changes to the role nurses had played in previous decades. First, it was considered necessary to reduce the number of nurses, formerly the majority, practising in hospitals in order to increase the percentage working in the community. Concern to meet the seemingly most immediate needs of the sick and the priority given to specialised care had delayed the entry of nurses into public health services and the adoption of a community-based approach. The WHO also noted the need to modify traditional relations between the health professions, in favour of teamwork:

\footnotetext{
"Whatever the function in which she is engaged, the public health nurse at all times works closely with other members of the health team -sharing information, consulting on plans, reporting on items of mutual interest to physicians, hospital nurses, sanitarians, nutritionists, social workers, teachers, responsible government officials and all others who are concerned with the health of the public." 79
}

In addition, the WHO recommended a change of approach in nurse teaching. It proposed replacing hospital-based teaching for nursing courses delivered by universities, providing a higher quality education that besides subjects such as epidemiology and basic research methodology would also include

71 WHO 1958, 392-3.

72 WHO 1962, 8.

73 WHO 1962, 11.

74 WHO 1959, 5; See also WHO 1962, 12.

75 WHO $1959,8$.

76 WHO $1959,9$.

77 WHO 1959, 17.

78 WHO 1959, 10

79 WHO 1959, 5. 
various others related to the social sciences, combined with placements in public health nursing services. ${ }^{80}$

In its recommendations to improve nursing, the WHO also placed importance on taking steps to heighten public regard for nurses. A number of measures would be required to help create the necessary context for the WHO's proposals to prosper in the following decades, especially with regard to training and development of the discipline and profession. These included providing adequate legal protection, especially with regard to responsibility in delegated functions and the regulation of professions; ensuring suitable allocation of tasks according to the training received: "Nurses should not be required to perform work that could be entrusted to auxiliary or administrative staff"; $; 1$ establishing mechanisms that would enable nurses to access leadership and management positions; ${ }^{82}$ endowing nurses with the capacity to take decisions, in order to stimulate motivation; ${ }^{83}$ and fostering continuing education through professional development programmes. These proposals were all included in the primary health care declaration published following the Alma-Ata Conference in $1978 .{ }^{84}$

\section{Conclusions}

This paper has analysed the influence of international organisations in the process of socialisation and professionalisation of public health nursing in Europe, and the role of nursing experts working within the framework of these organisations.

By the 1920s, international health institutions and organisations had become aware of the need for appropriately trained public health nursing professionals equipped to carry out community-based interventions. However, their strategies and influence as regards applying nursing principles to health care changed over the course of the $20^{\text {th }}$ century. In the $1920 \mathrm{~s}, 1930 \mathrm{~s}$ and 1940s, prior to the creation of the WHO, the LoN advocated a model that was clearly influenced by the proposals of the Rockefeller Foundation, in which nurses were to some extent seen as instrumental to achieving public health. It was not until the creation of the WHO and its expert committees on nursing that nurses would begin to make unique contributions to this goal,

80 WHO 1962, 12.

81 WHO 1959, 16.

82 WHO 1959, 17.

83 WHO 1959, 18.

84 WHO 1978. 
for example through community mediation and health promotion and education.

The work of nursing experts such as Goff, who played an important role in the League of Nations Hygiene Committee, and other nursing experts on the WHO's Advisory Committees, underpinned systematic efforts to establish appropriate training in public health nursing and organised effective nursing services in Europe.

Through the example of public health nursing, this research has revealed changes over time in attitudes towards the contribution of nursing. These results shed light on the construction of a health care model that had its origins in the medical community of the inter-war period and culminated in the primary health care declaration issued following the Alma-Ata Conference in 1978.

The history of nursing is still a recent subject of study, and within this field, the adoption of an international perspective and the study of the exchange of health care knowledge and practices are even more so. Consequently, the present study is in line with trends in nursing history research ${ }^{85}$ highlighting the need for a greater international focus.

\section{Bibliography}

Andresen, Astri/Tore Groenlie (eds.), Transferring Public Health, Medical Knowledge and Science in the $19^{\text {th }}$ and $20^{\text {th }}$ Century (Bergen 2007)

Barona, Josep L., From Hunger to Malnutrition. The Political Economy of Scientific Knowledge in Europe 1918-1960 (Brussels 2012)

Barona, Josep L., The Rockefeller Foundation, Public Health and International Diplomacy, 1920-1945 (London 2015)

Barona, Josep L./Josep Bernabeu, La Salud y el Estado. El movimiento sanitario internacional y la administración Española (Valencia 2008)

Bernabeu-Mestre Josep/Concepción Carrillo-García/María Eugenia GalianaSánchez/María Pilar García-Paramio/Eva María Trescastro-López, "Género y profesión en la evolución histórica de la Enfermería Comunitaria en España", Enfermería Clínica 23 (6) (2013) 284-289

Bernabeu-Mestre, Josep/María Eugenia Galiana-Sánchez, "La colaboración interdisciplinar en la transmisión del conocimiento de las ciencias de la salud y la internacionalización de las prácticas sanitarias", in: M.I. Porras Gallo/B. Gutiérrez Rodilla/M. Ayarzagüena Sanz/J. de las Heras (eds), Transmisión del conocimiento médico e internacionalización de las prácticas sanitarias: una reflexión histórica, Universidad de Castilla-La Mancha (Ciudad Real 2011) 363-366

Bernabeu-Mestre, Josep/María Eugenia Galiana-Sánchez, "Salud comunitaria y acción social en el control epidemiológico del tracoma infantil (1932-1939)", Asclepio 2 (2011) 507-520

85 Davies 2007, Rafferty 2014, Mortimer/McGann 2008, Boschma 2008, 2014. 
Bernabeu-Mestre, Josep/María Eugenia Galiana-Sánchez/Angela Cremades Monerris, "Environment and health with respect to a poverty-related disease: the epidemiology of trachoma in Spain, 1925-1941", Hist Cienc Saude Manguinhos 20 (2013) 1605-1619

Bernabeu-Mestre, Josep/María Encarnación Gascón-Pérez, Historia de la enfermería de Salud Pública en España (1860-1977) (Alicante 1999)

Bernabeu-Mestre Josep/Enrique Perdiguero/Josep L., Barona, "Determinanti della mortalità infantile e transizione sanitaria. Una riflessiones a partire dall'esperienza spagnola”, in: Salute, Malaita e sopravivenza in Italia fra '800 e 900' (Udine 2007) 175-193

Borowy, Iris, Coming to terms with world health: The League of Nations Health Organisation, 1921-1946 (Frankfurt-a-M 2009)

Boschma, Geertje, "Writing International Nursing History: What Does It Mean?" Nursing History Review 16/1 (New York 2008) 9-12

Boschma, Geertje, "International Nursing History: The International Council of Nurses History Collective and Beyond", Nursing History Review 22 (2014) 114-118

Brooks, Jane /Anne Marie Rafferty, "Education and role conflict in the health visitor profession, 1918-39", Nursing Inquiry 17/2 (2010) 142-150

Davies, Celia, "Rewriting nursing history again?” Nursing History Review 15 (2007) $11-28$

Dingwall, Robert/Anne Marie Rafferty/Charles Webster, An introduction to the social history of nursing (London 1988)

Dubin, Martin D. "The League of Nations Health Organization", in Paul Weindling (ed.), International health organisations and movements, 1918-1939 (Cambridge 1995) 56-80

Farley, John, The cast out disease: a history of the International Health Division of the Rockefeller Foundation (1913-1951) (Oxford 2004)

Galiana-Sánchez, María Eugenia, Bernabeu-Mestre, Josep, “Género y desarrollo profesional: las enfermeras de salud pública en la España del período de entreguerras, 1925-1939", Feminismos 18 (2011) 225-248

Galiana-Sánchez, María Eugenia/Josep Bernabeu-Mestre/María Pilar GarcíaParamio, "La enfermería de salud pública y los inicios de la Organización Mundial de la Salud (OMS). Reflexiones desde el caso español (1948-1962)", in M.I. Porras Gallo/B., Gutiérrez Rodilla/M. Ayarzagüena Sanz/J. de las Heras, (eds), Transmisión del conocimiento médico e internacionalización de las prácticas sanitarias: una reflexión histórica, Universidad de Castilla-La Mancha, (Ciudad Real 2011) 385-389

Gascón-Pérez, Encarnación/María Eugenia Galiana Sánchez/Josep BernabeuMestre, "La acción social de las visitadoras sanitarias", Revista de Trabajo Social y Salud 43 (2002) 149-174

Goff, Hazel Avis, "Trends in the Development of Public Health Nursing in Europe" International Nursing Review (1931)

Goff, Hazel Avis, "Report of study of Public Health Nursing in Europa", International Nursing Review (1932)

Huertas Rafael, Organización sanitaria y crisis social en España: la discusión sobre el modelo de servicios sanitarios públicos en el primer tercio del siglo $X X$, Fundación de Investigaciones Marxistas (Madrid 1995) 
Irwin, Julia "Nurses Without Borders: The History of Nursing as U.S. International History" Nursing History Review 19 (2011) 78-102

Lapeyre, Jaime/Sioban Nelson, "The "old internationals": Canadian nurses in an international nursing community" Canadian Journal of Nursing Leadership 23/4 (2010)

McGann, Susan, "Collaboration and Conflict in International Nursing, 1920-1939", Nursing History Review 16/1 (2008) 29-57

Mezquita López, Manuel, "La lucha contra el tracoma en la provincia de Almería" Revista de Sanidad e Higiene Publica 29 (1955) 451-512

Mortimer, Barbara; McGann Susan (eds.), New directions in the History of Nursing. International perspectives (Abingdon 2005)

Palmieri, Daniel, "An institution standing the test of time? A review of 150 years of the history of the international committee of the Red Cross" International Review of the Red Cross 94/888 (2012) 1-26

Pozzi, Lucia/Josep Bernabeu-Mestre/María Eugenia Galiana-Sanchez, "Le modèle explicatif des maladies infectieuses associées à la misère et à la pauvreté: l'expérience espagnole et italienne dans la première moitié du $\mathrm{XX}^{\mathrm{e}}$ siècle", Histoire, économie et société 36/1 (2017) 39-56

Rafferty, Anne Marie "Internationalising nursing education during the inter-war period" in: Weindling Paul (ed.), International health organisations and movements, 1918-1939 (Cambridge 1995) 266-282

Rafferty, Anne Marie, "Tiptoeing Towards a History of Nursing in Europe" Nursing History Review 22 (2014) 107-113

Ramos Ferreira, Oscar Manuel. História da escola técnica de enfermeiras (19401968), Aprender para ensinar e profissionalizar, Tesis Doctoral (Lisboa 2012).

Red Cross League. http://www.nobelprize.org/nobel_prizes/peace/laureates/1963/ red-cross-league-facts.html (2015)

Roberts, Mary M. Impressions of Nursing in Jugoslavia and Hungary, American Journal of Nursing (1931)

Rodríguez Ocaña, Esteban/Ferran Martínez Navarro, Salud Pública en España. De la Edad Media al siglo XXI. Escuela Andaluza de Salud Pública, Consejería de Salud (Granada 2008)

Ruesta Marco, Santiago et al., "Organización de los servicios de Higiene rural. Normas que aconseja la experiencia adquirida para su total desenvolvimiento" in: Nájera Angulo L. (coord.) Primer Congreso Nacional de Sanidad, Ministerio de la Gobernación t. I (Madrid 1934) 235-279

Selfa Martínez, Enrique, "Consideraciones sobre la lucha contra las causas de ceguera", Revista de Sanidad e Higiene Publica 5 (1940) 163-177

Socias, Arnaldo, Delgado, J, "Estudio de los factores epidémicos en la endemia tracomatosa", Revista de Sanidad e Higiene Publica 13/11-12 (1939) 3-31

Steller, Maria, Development of nursing in Hungary, Methods and Problems of Medical Education, Rockefeller Foundation (New York 1932)

Verdes Montenegro, José, "Las instructoras sanitarias", La Visitadora Sanitaria 1 (1934) 11-12

Weindling, Paul, "Social Medicine at the League of Nations Health Organization and the International Labour Office Compared", in: Paul Weindling (ed.), International health organisations and movements, 1918-1939 (Cambridge 1995) 134-153 
Weindling, Paul, "Philanthropy and World Health: The Rockefeller Foundation and the League of Nations Health Organisation", Minerva 35 (1997) 269-281

WHO, Technical Report Series, no. 24, Expert Committee on Nursing, Report of the First Session (Geneva 1950)

WHO, "Nursing" in: The First Ten Years of the World Health Organization (Geneva 1958) 391-402

WHO, Technical Report Series, no. 167, Public Health Nursing, Fourth Report of the Expert Committee on Nursing (Geneva 1959)

WHO, Aspects of Public Health Nursing (Geneva 1962)

WHO, Technical Report Series, no. 347, WHO Expert Committee on Nursing, Fifth Report (Geneva 1966)

WHO, Technical Report Series, No. 558, Nursing and Community Health, Report of a WHO Expert Committee (Geneva 1974)

WHO, Atención Primaria de Salud, "Conferencia Internacional de Alma-Ata" (Geneva 1978)

$\mathrm{XV}^{\text {th }}$ International Red Cross Conference. Training of Nurses and Voluntary Aids in Their Duties in Case of War or Public Calamity (Tokyo 1934) Summary 